\title{
A digitalizációs folyamat az agrárvállalatok körében, avagy egy kérdőíves kutatás eredményei
}

\section{Digitalization Process by Agricultural Companies, or the Results of a Questionnaire Survey}

\section{O. BERTA SZABÓ1 ${ }^{1}$, CS. JUHÁSZ ${ }^{2}$}

${ }^{1}$ Nyíregyházi Egyetem, Gazdálkodástudományi Intézet, berta.olga@nye.hu ${ }^{2}$ Debreceni Egyetem, Gazdaságtudományi Kar, Vezetés- és Szervezéstudományi Intézet; Szervezés és Kommunikáció Tanszék; juhasz.csilla@econ.unideb.hu

Absztrakt. Az „információs társadalom” kifejezés az 1960-as évek elejének japán társadalomtudományában jelent meg először (Z. Karvalics, 2007). Jelentős változáson ment át a fogalom értelmezése az elmúlt évtizedek alatt, ami mutatja, hogy a dinamikusan fejlődő társadalmak az információ rohamos fejlődésének, az információgazdálkodásnak és a digitális világ dinamizmusának köszönhetően folyamatos változás alatt állnak. Az információ és az informatika szoros kapcsolata és összefüggése alapvető tényező lett a mai kor társadalmaiban, a szervezetek életében, amely megkerülhetetlen, olykor komoly vitákat és mély változásokat generál. A gazdasági szereplőknek szükségszerüen rugalmasnak kell lenniük a technológiai változásokkal szemben. Elég az ipari forradalom idejére gondolnunk, amikor a modern szövőgépek ellepték a gyárakat. Ellenkező esetben a változásnak ellenálló, rugalmatlan szervezet nem marad fenn a fejlödő és folyamatosan változó, dinamikus gazdasági környezetben. Természetesen igaz ez a mezőgazdaság esetében ugyanúgy, mint más nemzetgazdasági ágazatoknál. Feltételezésem, melyek alapján a kérdőivemet összeállítottam egyrészrôl az volt, hogy vállalatirányítási rendszereket a tevékenység diverzifikáltságával növekvő mértékben használnak a vállalkozások a mezőgazdaságban. Ugyanakkor úgy véltem, hogy a vállalkozás mérete is befolyással lehet az információs technológia (továbbiakban IT) használatára, így reméltem, erre vonatkozóan is egyértelmú adatokkal szolgál majd a kutatásom.

Kulcsszavak: digitalizáció, agrárium, kutatási eredmény

Abstract. The term "information society" first appeared in Japanese social science in the early 1960 s (Z. Karvalics, 2007). The interpretation of the concept has undergone significant changes over the past decades, showing that dynamically developing societies, which are undergoing constant changes due to the rapid development of information, information management and the dynamism of the digital world. The close relationship and connection between information and information technology has become a fundamental factor in the societies of today, the organizations life, which generates inevitable, sometimes serious debates and profound changes. Economic operators must necessarily be resilient to technological change. We should think of the time of the Industrial Revolution, when modern weaving machines flooded the factories. Otherwise, a resilient organization will not survive in an evolving and ever-changing dynamic economic environment. Of course, this is true of agriculture as well, just as it is for other sectors of the national economy. On the one hand, my assumption on the basis of which my questionnaire was compiled was that enterprise management systems 
are increasingly used by enterprises in agriculture due to the diversification of activities. At the same time, I assumed that the size of a business could influence the use of information technology (hereinafter IT), so I hoped that my research would provide reliable data on this as well.

Keywords: digitization, agriculture, research results.

\section{Bevezetés}

A német mezőgazdasági gazdálkodókat tömörítő szervezet, a Deutscher Bauernverband évente összeállítja helyzetjelentését, melyben áttekintik és összegezik az agrárgazdasági kérdéseket, feladatokat, kihívásokat. Legújabb jelentésükben kiemelik, hogy egy gazdálkodó az 1900-as években 4 embert látott el élelemmel, 1950-ben már 10 főt, napjainkban pedig 135 fő ellátását oldja meg. (Internet 1) Ezek a számok is mutatják, mekkora kihívás a mezőgazdaságban az egyre hatékonyabb, ugyanakkor gazdaságos termelés. A tanulmány kiemeli azt a tényt is, hogy az agrárium és az agrárgazdaság vagy agribusiness nem egymással azonos fogalmak. Míg az agrárium néhány százalékát adja csak a GDP-nek, addig az agribusiness a teljes hazai termelés és kereskedelem akár 10-15 százalékát is elérheti. Ezért is fontos, hogy ennek a szektornak a modern, digitalizált világgal való kapcsolatát erősítsük és fejlesszük. Kutatásomban a magyar kettős könyvvezetést alkalmazó mezőgazdasági vállalkozások informatikai jellemzőit mutatom be, egy kérdőíves vizsgálat eredményei alapján. Érdeklődésem arra irányult, hogy milyen tényezők hatnak a vállalkozások informatikai rendszerhasználati szokásaira, mely rendszereket használják és milyen okok állnak a háttérben. Fontosnak tartom kiemelni, hogy csak társas vállalkozások kerültek bele a vizsgálatba, mert az egyéni vállalkozások nagy száma nem tette lehetővé reprezentatív minta kialakítását és a vizsgálatba történő bevonását. Eredményeim jól mutatják a jelenlegi helyzetet és a kapcsolatokat az informatikai felhasználások döntéshozatalánál.

\section{A kutatás rövid bemutatása}

2017 februárjában a PREGA ${ }^{1}$ konferencián (Internet 2) a plenáris szekció előadói kiemelték, hogy a legfontosabb kitörési pontok, mint a hatékonyság növelése, többlábon állás erősítése lehet a mezőgazdaságban. Ugyanakkor Magyarországon is elérte az agráriumot az „informatikai forradalom”, fontosnak tartották felhívni a figyelmet arra, hogy a magyar agrárgazdaságnak is lépést kell tartania a világ mezőgazdaságával. A keletkezett haszon pedig nemcsak pénzbeli, hanem környezeti, társadalmi, valamint erkölcsi lehet, hiszen az agárszakembernek és az informatikusnak egyaránt együtt kell működnie a közös cél érdekében.

\subsection{A diverzifikáció szakirodalmi vizsgálata}

A vizsgálat kezdetekor a diverzifikáció fogalmának tisztázása érdekében tanulmányoztam a hazai és nemzetközi szakirodalmat, hogy pontos képet alkothassak a statisztikai vizsgálatot megelőzően. Több meghatározásból indulhattam ki, melyek segítettek a fogalom minél pontosabb körülhatárolásában. A „diverzifikáció” fogalmát az Idegen szavak és kifejezések szótára (Bakos, 2002; p. 189) a következőképp fogalmazza meg: „a termelő vállalat gyártási profiljának a várható piaci lehetőségek jobb kihasználására

\footnotetext{
${ }^{1}$ Precíziós Gazdálkodási és Agrárinformatikai Konferencia
} 
irányuló tudatos bővítése, a vállalat működési körének kiterjesztése; több lábon állás". Tanulmányaim során több elmélet is azt támasztotta alá, hogy a specializáció és a diverzifikáció egymással ellentétes, egymásnak ellentétesen ható folyamat, mindenképpen a tevékenységek számának és szerteágazóságának növekedése irányába hat. A túlzott diverzifikáció azonban esetleg negatív irányba ható folyamat is lehet: akadályozhatja az optimális termelési színvonal és méret kialakítását, továbbá a kapacitás elaprózódását is. A diverzifikáció megkülönböztetett alaptípusai Szakál (2000) szerint, a vertikális, teljes termékskála típusú és oldalirányú vagy körkörös diverzifikáció. A vertikális diverzifikáción a vállalat valamely meglévő tevékenységének termékpályájához tartozó, kapcsolódó tevékenység termelési szerkezetbe való bevonását értjük. A teljes termékskála típusú diverzifikáció során a diverzifikáció alapja a már meglévő erőforrás-rendszer vagy egy - már kialakított - technológia. Ilyenkor a vállalat olyan új tevékenységeket von be a termelési szerkezetbe, amelyek megvalósíthatóak már adott eszközökkel, technológiákkal. Jellemzője, hogy a vállalkozás meglévő tapasztalataira, kapcsolataira épül, ezzel csökkentve a diverzifikáció kockázatát. Az oldalirányú vagy körkörös diverzifikáció esetén a termelés szerkezetébe bevont új tevékenység a már meglévőkkel semmilyen kapcsolatban nincs.

Kovács (2009) nyomán Hamza (2011) is megállapítja, hogy a specializáció és a diverzifikáció ellentétesen hat a gazdaság jövedelmének nagyságára, a jövedelem ingadozására. A specializáció magasabb jövedelmet eredményez a legkifizetődőbb tevékenység(ek) előtérbe állítása, a méretgazdaságosság, továbbá a nagyobb szaktudás és a színvonalasabb menedzsment elérésének lehetősége révén, ugyanakkor jelentősen fokozza a jövedelem-kockázatot. A gazdálkodók azonban gyakran hajlandók kisebb várható jövedelemmel megelégedni, ha így csökkenthető a jövedelem ingadozása, a kockázat. A kockázat csökkentésének egyik eszköze lehet a diverzifikáció, ami elkerülhetővé teszi, hogy a vállalkozás sikere egyetlen terméktől, annak hozamától és árának alakulásától függjön.

Az agrár-közgazdaságtanban azonban az utóbbi években új fogalmi rendszer alakult ki a nemzetközi szakirodalomban. Az új fogalom a farmdiverzifikáció, mely más megközelítést alkalmaz a diverzifikációra és a mezőgazdasági vállalkozások tevékenységének kiterjesztésére vonatkozóan. E szerint a megközelítés szerint a gazdaság vezetői és segítő családtagjaik jövedelemszerző tevékenységeinek kibővítése áll a középpontban, főként a mezőgazdasági alaptevékenységeken kívüli tevékenységek végzésével (Hamza, 2011). Ez attól függően, hogy a gazdaságban, a gazdaság erőforrásainak felhasználásával végzett, vagy gazdaságon kívül folytatott tevékenysége(ke)t takar, nevezhető gazdaságon belüli „on-farm” és gazdaságon kívüli „off-farm” diverzifikációnak. A magyar szakemberek is gyakran alkalmazzák a „farmdiverzifikáció” kifejezést, mellyel érzékeltetik a gazdasághoz, (amely alatt leginkább családi gazdaságot értik) mint alapegységhez való kötődést. Ezzel párhuzamosan nyert teret a pluriaktivitás fogalma is, amit leginkább „számos tevékenység”-ként adhatunk vissza. Kinsella (2000) szerint a pluriaktivitást vagy részidős farmgazdálkodást a gazdálkodástól való elmozdulásként, stratégiaként is tekinthetjük, ugyanakkor a pluriaktivitás olyan faktor is lehet, mely helyben tartja az embereket vidéken, mérsékeli a gazdaságok számának csökkenését és erősíti a helyi szolgáltatásokon alapuló tevékenységet. Az Eurostat Farm Structure Survey (FSS) definíciója szerint (Internet 3) a „pluriactivity” fogalmába tartozik a saját gazdaságában végzett minden - nem mezőgazdasági - tevékenység, (pl. a falusi turizmus), más gazdaságban végzett díjazott tevékenység, illetve nem mezőgazdasági vállalkozás alkalmazásában zajló munkavégzés. A 
diverzifikáció alatt minden olyan tevékenységet érthetünk, amely nem tartozik a hagyományosnak mondható mezőgazdasági tevékenységek közé, azonban használja a gazdaság erőforrásait és termékeit, tehát szorosan kapcsolódik a gazdasághoz, vállalkozáshoz.

\subsection{A statisztikai vizsgálat alapja}

Vizsgálatomban egyszerű, véletlen mintavételi eljárást alkalmazva kérdeztem meg a kettős könyvvezetésú mezőgazdasági vállalkozásokat, kérdőíves felmérés segítségével. A kutatás fő vázát egy kérdőíves megkérdezés adta. A kérdőív összeállítása során segítséget jelentett egy előzetes, félig strukturált mélyinterjú keretében végzett vizsgálat, amikor felmértem 10 különböző méretű mezőgazdasági vállalkozásnál, hogy milyen fóbb kérdésekre érdemes összpontosítanom a téma keretei között. A vizsgált területeket a fő kérdéscsoportok tematikája alapján építettem fel és mutatom be az eredményeket is, ezek a következők: a vállalkozás és vezetése; az információgazdálkodással kapcsolatos kérdések; a vállalkozás számítógépes rendszerére vonatkozó kérdések, valamint a vállalkozás terveivel, kapcsolatrendszerével, a vezetéssel kapcsolatos kérdéskör. (Berta, 2018)

A minta kialakításánál fő motiváló tényező az volt, hogy „egyszerű véletlen mintavételt használunk homogén, véges elemszámú sokaság esetén, amikor a mintát visszatevés nélkül választjuk $\mathrm{ki}$, minden lehetséges „ $\mathrm{n}$ ” elemű minta kiválasztásának azonos valószínűséget biztosítva”, ami a reprezentativitás előfeltétele (HunyadiVita; 2008; p 45.). A mintavétel során csak kettős könyvvezetésű vállalkozásokat vizsgáltam meg, mert olyan nagy számban van jelenleg hazánkban őstermelő és egyéni vállalkozó a mezőgazdaságban, ami egy reprezentatív vizsgálatot nem tett lehetővé. Az adatok alapján az adott időszakban 433726 egyéni vállalkozás múködött a mezőgazdaságban, ebből 415611 őstermelő (KSH²; 2013). Emellett olyan nagy mintára lett volna szükség, amit lehetetlennek túnt lekérdezni a rendelkezésemre álló idő alatt. A mintavételhez szükséges adatbázis összeállítása során a KSH-nál sikerült egy olyan statisztikai adatsort találnom, mely a regisztrált mezőgazdasági vállalkozásokat összesítette. Időközben az Agrárgazdasági Kutató Intézettel (továbbiakban AKI) is felvettem a kapcsolatot, mert egy közzé tett felmérésük eredményében a kettős könyvvezetésú mezőgazdasági vállalkozásokra vonatkozóan egy összesített listát találtam, megyei szintre lebontva és összesítve a vállalkozásokat. A tőlük kikért lista lett az alapsokaságot biztosító adatbázisom. A felmérésem alapjául szolgáló adatsor az AKI 2010. évi összesítése alapján készült, a lejegyzett kettős könyvvezetésú vállalkozásainak jegyzéke biztosította, amiben 10648 mezőgazdasági vállalkozás szerepel. Azért ezt választottam, mert így rendelkezésemre állt egy részletes adatbázis, melyben szerepeltek a mezőgazdasági vállalkozások legfontosabb adatai. (Berta, 2018)

\section{A vizsgált minta rövid bemutatása}

A kutatás fő vázát egy kérdőíves megkérdezés adta. Ahogy a szakirodalomban Babbie (2008) megfogalmazza, egy felmérés egy bizonyos népesség jellemzőit egy adott populációból vett minta összegyűjtésével és a statisztikai módszertan felmérésével értékeli. A kérdőív alapvető céljai: összegyűjti a megfelelő adatokat, biztosítja az adatok összehasonlíthatóvá tételét és az elemzésre való alkalmasságot, minimalizálja a félreértést a kérdés megfogalmazásában és feltárásában, végül kérdéseket tesz fel és változtat Brace szerint (2008). A kérdőívem összeállítása során segítséget jelentett egy előzetes, félig strukturált mélyinterjú keretében végzett vizsgálat, amikor felmértem 10 különböző

\footnotetext{
${ }^{2}$ Központi Statisztikai Hivatal
} 
méretű mezőgazdasági vállalkozásnál, hogy milyen főbb kérdésekre érdemes koncentrálnom a téma keretei között. Ezen közvetlen megbeszélések, fókuszcsoportos interjúk eredményei, tapasztalatai alapján állítottam össze a kérdőív végleges kérdéseit és az EvaSys nevű programban alakítottam ki a végleges formátumát. Ezek a célinterjúk rávilágítottak arra is, hogy ne csupán az információval való belső gazdálkodásra, hanem általános és a mai kornak megfelelő egyéb kérdésekre is fókuszáljak. (Szabóné Berta, 2019)

A reprezentatív minta kialakítása során a földrajzi és tevékenység szerinti csoportok adatait vettem figyelembe, és állítottam össze egy olyan alapsokaságot, ami alapján a teljes magyarországi mezőgazdaság jellemezhető. A végleges mintanagyság 270 mezőgazdasági vállalkozás lett, amelynek tulajdonosát vagy döntéshozója válaszolt a kérdésekre. A beérkezett kérdőíveket az elemzés megkezdése előtt ellenőriztem és az esetleges hiányosságokat, pontatlanságokat utólagos lekérdezéssel javítottam. A minta feldolgozást és elemzést SPSS és MS Excel programok használatával végeztem. Az Excel programot az eredmények rögzítésénél, alapszámítások végzésénél, és grafikonok készítésénél használtam. SPSS program segítségével végeztem el a statisztikai elemzéseket, melyek közül kiemelt fontosságú volt az eredmények közötti összefüggések vizsgálata. (Szabóné Berta, 2019)

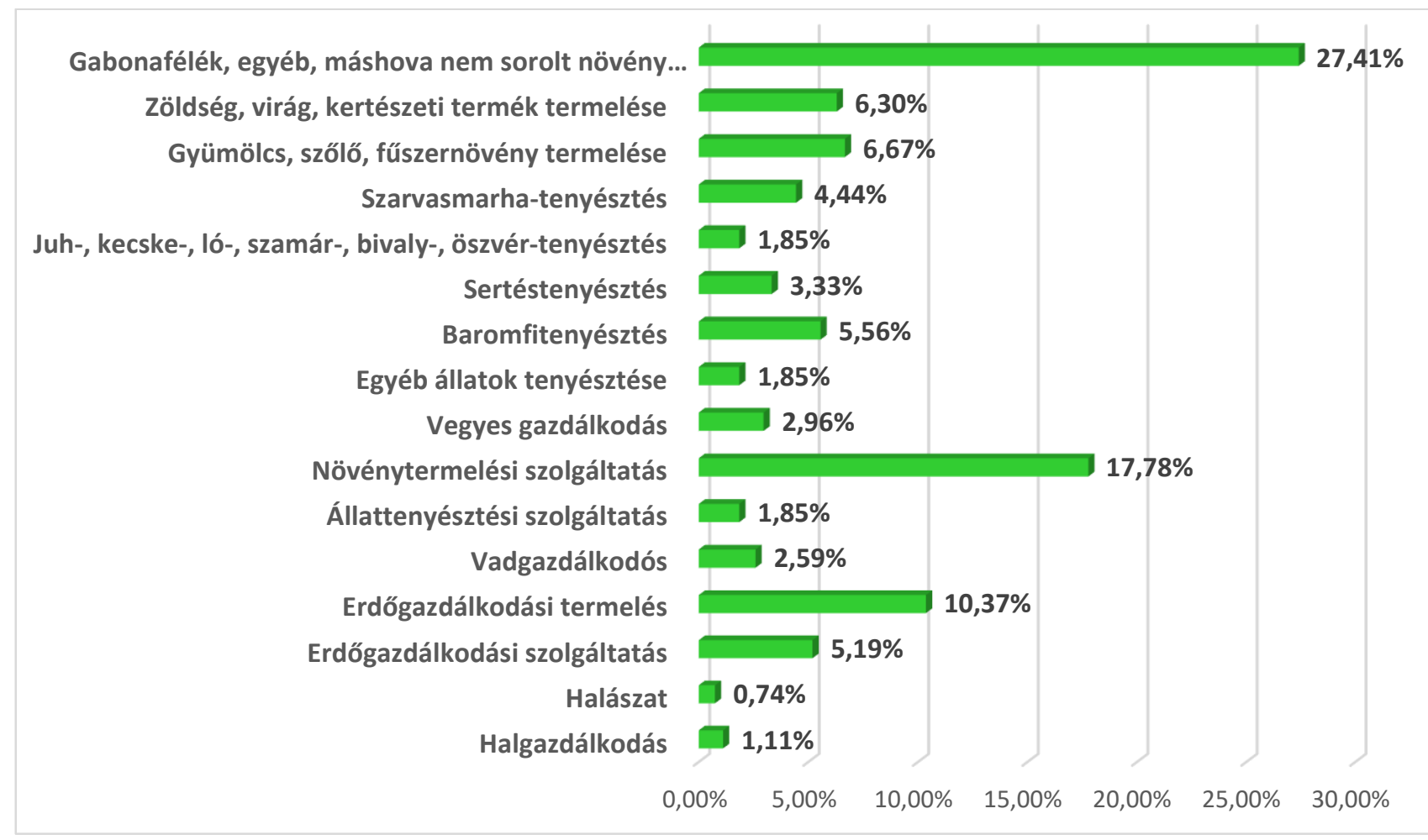

Forrás: Saját kutatás, 2017.; n=270

\section{1. ábra: A beérkezett kérdőívek tevékenység szerinti megoszlása a mintában}

A 1. ábrán a beérkezett kérdőívek alapján a mintában szereplő vállalkozások fő tevékenységi körét összesítettem, ami megfelel a kiküldött kérdőívek arányának, biztosítva a reprezentativitás második rétegét. A legtöbb válaszadó a gabonafélék és egyéb máshova nem sorolt növények termelése főtevékenységben szerepel, míg a halászat területén még az 1 százalékot sem érik el a válaszadók a teljes mintában, ugyanúgy, mint az alapsokaság esetében, ahol 0,7\%-nyi mindössze a halászati tevékenységet végző mezőgazdasági szervezet. 
Megvizsgáltam a minta vállalkozási formára vonatkozó összetételét. is. A Kft., mint társasági forma jelentős túlsúllyal bír a mezőgazdasági vállalkozások körében is, 61,11\%-kal. Jellemző gazdálkodási forma még a mintában a részvénytársaság (14,07\%), a betéti társaság 12,96 százalék. Ezek mellett viszonylag gyakori a szövetkezet, mint vállalkozási forma 7,7\%. Ezek együttesen 90\%-nál nagyobb mértékben fedik le a mezőgazdasági vállalkozások társasági formáit.

A mintát megvizsgálva kirajzolódik, hogyan oszlanak meg a vállalkozások, ha az éves nettó árbevételt vizsgálom meg méretkategóriánként. Ahogy a teljes sokaságban, úgy a mintában is a mikrovállalatok dominálnak. Ez a kategória 64,44 százalékot jelent a mintában, ami azért ilyen jelentős, mert ha 300 Ft/Euro árfolyamot veszek alapul, abban az esetben is 600 millió Ft árbevételt feltételez a kategória felső határa. Kisvállalat 24,07 százalékot, középvállalat 10,37 százalékot tesz ki a mintán belül. Nagyvállalat 1,11\% válaszadót jelentett, ami nagyon kedvező arány, tekintve, hogy ebben a méretkategóriában nagyon kevés a teljes sokaságban is az ágazati szereplő.

\section{Az integrált belső számítógépes rendszer használatának tevekénység alapú vizsgálati eredményei}

Ansoff (1957) szerint a diverzifikáció okai egy vállalat növekedési koncepciójával vannak elsősorban összefüggésben. Ennek megfelelően a hipotézisem megalkotásánál abból indultam ki, hogy minél összetettebb, diverzifikáltabb egy vállalkozás tevékenysége akár horizontális akár vertikális diverzifikáció esetén, annál inkább szüksége lesz egy, a vállalkozás egészét átfogó és integráló vállalatirányítási rendszerre a hatékonyabb és gazdaságosabb vezetés érdekében.

Az egyik hipotézisem az volt, hogy azok a mezőgazdasági vállalkozások használnak integrált vállalati informatikai rendszereket ma Magyarországon, amelyek tevékenysége a diverzifikáltság irányába mutat, azaz szerteágazóbb és összetettebb tevékenységet folytatnak, szemben azokkal a vállalkozásokkal, melyek nem használnak ilyen integrált rendszereket a munkájuk során.

A vizsgálatot a hipotézishez kapcsolódó adatok feldolgozásával és elemzésével kezdtem. Feltételeztem a vizsgálatom kezdetekor, hogy a tevékenységek diverzifikáltsága, jelentős befolyással van a magyar kettős könyvvezetésű mezőgazdasági társaságok integrált vállalatirányítási rendszer használatára, illetve IKT használatára. Ennek bizonyítására feltettem a tevékenységek összetettségére vonatkozó kérdést, valamint megkérdeztem a vállalkozásokat, hogy mit használnak az említett rendszerek közül. A tevékenységeket az elemzés során összesítettem az SPSS adatsorban és ezek adták meg az egyes válaszadók által végzett tevékenységeket.

A hipotézis igazolására először az F-próbát használtam, ami az összehasonlítás alapja varianciaanalízis esetében, mely az átlagok különbségeit jellemző sokaságok közötti varianciát hasonlítja össze a véletlen ingadozást jellemző - sokaságon belüli - varianciával. Vagyis az alapfeltevés az, hogy nincs eltérés az átlagok között. Amennyiben a szignifikanciaszint kisebb a 0,05 értéknél, abban az esetben el kell vetni a nullhipotézist, vagyis van kapcsolat a tevékenység összetettsége, diverzifikáltsága és az integrált rendszer használata között. 
A tevékenység diverzifikáltságának értékeit Lázár (2009) javaslatai alapján értelmeztem. Így az abszolút gyakoriság, vagyis hogy az egy rendelkezésre álló kategória hány értékéből számoltunk részátlagot, a vizsgálatom esetében 270 érvényes és 0 hiányzó értéket jelent. A végzett tevékenységek átlaga 4,29 és a medián (vagyis a középérték) 4,00 tevékenység lesz. A szórás értéke 2,318, a variancia pedig 5,373. Normál eloszlás esetén ez adja az adatok 95\%-át, ami teljesül ebben az esetben is. Az adatok alapján átlagosan az agrárszervezetekben 4 tevékenységet folytatnak, melyek eltérése, vagyis a szórás +/- 2 tevékenységet jelent.

Az 1. táblázat mutatja az első vizsgálat eredményét, melynek során az integrált számítógépes rendszereket használók és nem használók esetében hasonlítottam össze a diverzifikáltság középértékeit. Első lépésként az átlagokat állapítottam meg a két csoport esetében, melynek eredményeit a táblázat is mutatja: aki nem használ integrált rendszert átlagosan 3,65 tevékenységet folytat, míg az integrált rendszert használók átlagosan 5,6 tevékenységet folytatnak a vállalkozásban. Az integrált rendszert használó vállalkozások közül 89 jelezte, hogy használ ilyen rendszert és 181 esetében volt nemleges a válasz. Azok a vállalkozások, melyek használnak integrált vállalatirányítási rendszert 5,60 tevékenységet végeznek átlagosan, míg azok a vállalkozások, melyek nem használnak vállalatirányítási rendszert átlagosan 3,56 tevékenységet végeznek. A részátlagok mellett a program a teljes átlagot is kiszámítja, ami esetünkben 4,29 átlagos tevékenységet jelent.

\begin{tabular}{|c|c|c|c|c|c|c|c|c|}
\hline \multirow{2}{*}{\multicolumn{2}{|c|}{ Tevékenység diverzifikáltsága }} & \multirow[t]{2}{*}{$\mathbf{N}$} & \multirow[t]{2}{*}{ Mean } & \multirow[t]{2}{*}{$\begin{array}{c}\text { Std. } \\
\text { Deviation }\end{array}$} & \multicolumn{2}{|c|}{$\begin{array}{l}95 \% \text { Confidence } \\
\text { interval for mean }\end{array}$} & \multirow[t]{2}{*}{$\begin{array}{l}\text { Mini- } \\
\text { mum }\end{array}$} & \multirow[t]{2}{*}{$\begin{array}{l}\text { Maxi- } \\
\text { mum }\end{array}$} \\
\hline & & & & & $\begin{array}{l}\text { Lower } \\
\text { Bound }\end{array}$ & $\begin{array}{l}\text { Upper } \\
\text { Bound }\end{array}$ & & \\
\hline \multirow{3}{*}{$\begin{array}{l}\text { Tevékenységek } \\
\text { összesen }\end{array}$} & $\begin{array}{l}\text { Használok ilyen } \\
\text { rendszereket }\end{array}$ & 89 & 5,60 & 2,847 & 5,00 & 6,20 & 1 & 18 \\
\hline & \begin{tabular}{|l|} 
Nem használok \\
ilyen rendszereket
\end{tabular} & 181 & 3,65 & 1,676 & 3,40 & 3,89 & 1 & 10 \\
\hline & Összesen & 270 & 4,29 & 2,318 & 4,01 & 4,57 & 1 & 18 \\
\hline
\end{tabular}

Forrás: Saját kutatás, 2017. $\mathrm{n}=270$

1. táblázat: A varianciaanalízis numerikus változójának csoportonkénti statisztikája

A minimum és maximum értékének vizsgálata azért lényeges, mert ekkor derül ki világosan, hogy vane olyan szélsőséges érték, mely esetleg bekerülhetett az átlagba és torzíthatja az eredményeket. Ennek megfelelően nincs olyan érték, ami ennek a kritériumnak megfelelne és az elemzés eredményét torzíthatná. Folytatva az eredmények elemzését a 3. táblázat megmutatja, hogy az a 89 vállalkozás, amely használ integrált vállalatirányítási számítógépes rendszert, 5,6 tevékenységet végez átlagosan. Azon vállalkozások, melyek nem használnak ilyen rendszert átlagosan 3,65 tevékenységet folytatnak, míg az összes válaszadó tevékenységének középértéke átlagosan 4,29 tevékenység. Az elemzés során a konfidencia intervallumok közötti átfedést is vizsgáltam, az eredményekből kitűnik, hogy nincs közöttük átfedés. Már itt, ezekből az adatokból is levonható az a következtetés, hogy jelentős az eltérés a tevékenység diverzifikáltsága tekintetében azok között, akik használnak integrált vállalatirányítási rendszert, és azok között, akik nem alkalmaznak a munkájukban ilyen számítástechnikai megoldást. Ezt követően végeztem el az összehasonlítást a varianciaelemzés segítségével, ami már a szignifikáns összefüggést vizsgálta meg az adatok között. A statisztikai vizsgálat során 5 százalékos szignifikancia szinten végeztem az elemzést. Tudjuk, hogy az F próba értékének szignifikáns vizsgálatakor a p<0,05; 
azaz 5 százalékos érték az a határ, amely alatt még szignifikáns kapcsolatot tudunk jelezni az átlagok között.

A F próba alapján végzett összehasonlítása eredményeként megállapítható, hogy abban a tekintetben, hogy valaki használ-e integrált vállalatirányítási rendszert a vállalkozásában, szignifikáns összefüggés van az átlagosan végzett tevékenységek száma és az integrált számítógépes rendszer használata között. Ebben az esetben kiderül, hogy minél nagyobb a tevékenység diverzifikáltsága, minél több tevékenységet folytat a vállalkozás, annál valószínübb az integrált számítógépes rendszerek használata a vállalkozásban Az F próba eredményeként az F=49,839, míg a csoportokon belüli és a csoportok közötti szignifikanciaszint egyaránt $p<0,05$, ami esetünkben 0,000, vagyis erős kapcsolat van a két vizsgált tényező között. Megvizsgáltam az eredményeimet nem csak 5\%-os szignifikanciaszintnél, hanem 2\%-os szignifikancia szint alkalmazásával is. Arra voltam kíváncsi, ha szúkítem a hibahatárt, akkor milyen eredményt mutat majd a vizsgálatom. Az eredmények megmutatják, hogy a szignifikanciaszint szúkítésével nem romlik az eredményesség, tehát ebben az esetben is a p értéke kisebb, mint 2\%, vagyis a tevékenységek a 2 százalékos hibahatárt figyelembe véve is befolyásolják a rendszer használatot. Ugyanakkor elvégeztem az összehasonlításokat, melyek során a kapcsolatot néztem meg a végzett tevékenységek átlaga és a különböző, a vállalkozások által használt információs rendszerek között. Ennek eredményét szintén 5 százalékos szignifikancia szinten mutatja a 2. táblázat.

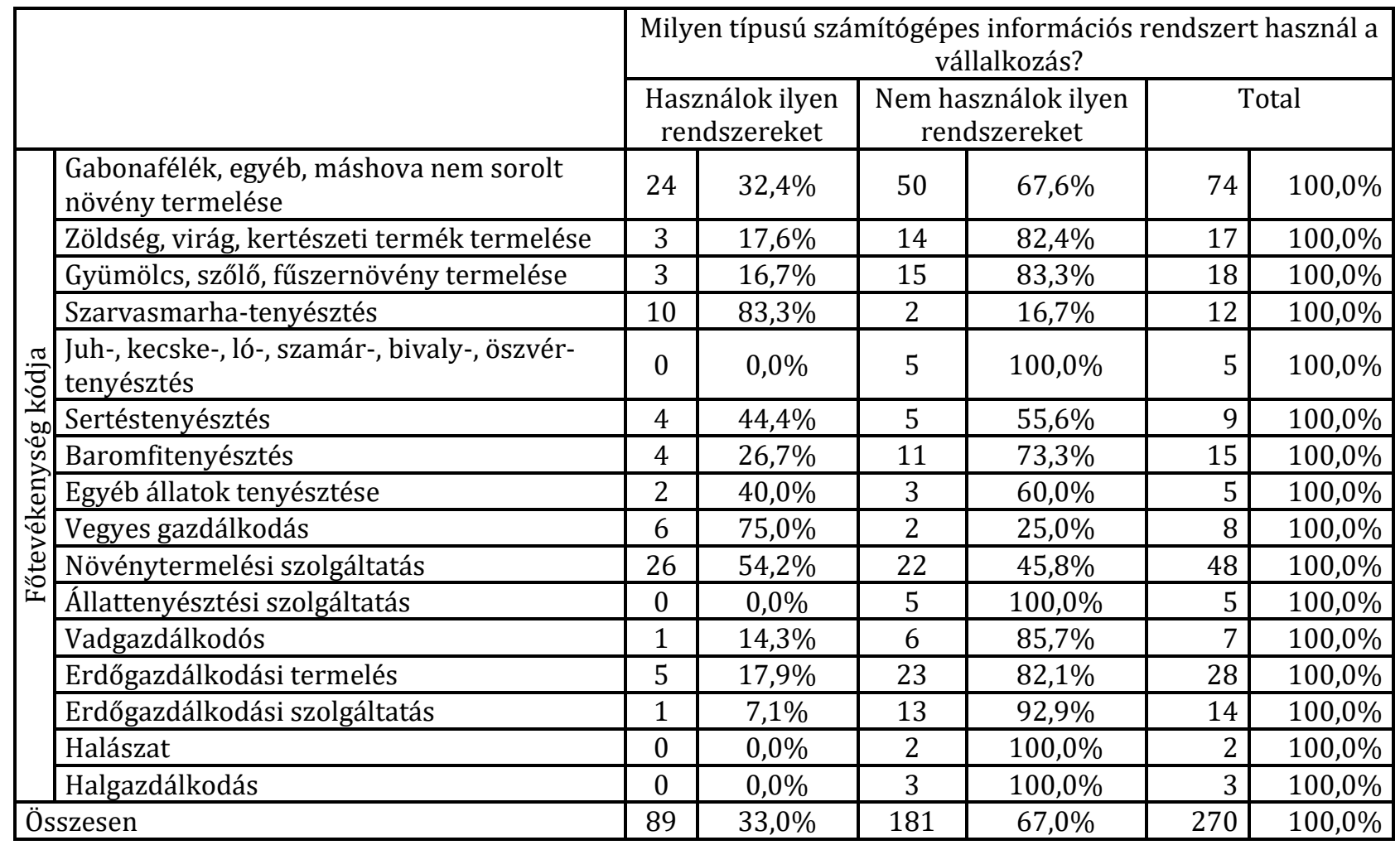

Forrás: Saját kutatás, 2017; $n=270$

2. táblázat: Kereszttábla elemzés a tevékenységi kódok alapján

Összefoglalóan elmondható, hogy nincs semmilyen szignifikáns kapcsolat abban a tekintetben, hogy átlagosan hányféle tevékenységet végeznek a vállalkozások és milyen információs rendszert használnak a munkájuk során. Ebben egyedül a szervezeti szintű információ rendszer használatánál talált a variancia analízisen alapuló elemzés erős, szignifikáns kapcsolatot. Itt az F= 5,078 szint mellett a 
p $<0,025$ szinten talált összefüggést az elemzés, ami azt jelzi, hogy az egyik legösszetettebb és szerteágazó integrált rendszer használata esetén van összefüggés a tevékenységek száma és az integrált rendszer típusának használata között.

A vizsgálatot a hipotézishez kapcsolódó adatok elemzésével folytattam annak érdekében, hogy pontosabb képet kapjak a végzett tevékenység és a rendszerhasználat összefüggéseinek természetéről. Ezt követően tehát tovább vizsgáltam a vállalkozásokat a főtevékenység alapján. Ehhez egy összesítést végeztem, mivel túl széttagolt lett volna az elemzésem. Így a főtevékenységek alapján 7 fő csoportot képeztem: növénytermesztés, állattenyésztés, vegyes gazdálkodás, mezőgazdasági szolgáltatás, vadgazdálkodás, erdőgazdálkodás és halgazdálkodás. Ez megfelel az ágazati főtevékenység szerinti besorolásnak és teljesen lefedi a vizsgált célcsoportot, a mezőgazdasági vállalkozásokat.

Mivel az adatsorom kereszttábla elemzést tett lehetővé, így ennek segítségével vizsgáltam a feltételezésem. A nullhipotézisem a kereszttábla elemzésekor az volt, hogy az adatok függetlenek egymástól, vagyis nincs kapcsolat a tevékenység diverzifikáltsága és az integrált vállalatirányítási rendszer használata között. A kereszttábla elemzése megmutatta, hogy el lehetet végezni a vizsgálatot: minden szükséges adat rendelkezésre állt. Összesítette az SPSS program a rendelkezésre álló adatokból, hogy az egyes főtevékenységenként, és átlagosan hányan és milyen arányban használnak a vállalkozásuk múködtetéséhez integrált ügyviteli rendszereket. Az elemzés során egyértelművé vált arányaiban is az eltérés, hogy a halgazdálkodás, vad - és erdőgazdálkodás, és a növénytermesztés főtevékenységet folytató vállalkozások az átlagos 32,96\% alatti mértékben használnak integrált vállalatirányítási rendszereket (14,3\% és 27,5\% között mozog az eredmény). Ezzel szemben főtevékenységként az állattartással, vegyes gazdálkodással és mezőgazdasági szolgáltatással foglalkozó vállalkozások ezt az átlagos 33,3\%-ot meghaladó mértékben alkalmaznak ilyen rendszereket munkájuk során. A legjelentősebb a rendszerhasználat a vegyes gazdálkodók esetében, hiszen ezeknek a vállalkozásoknak a háromnegyed része használ a gazdálkodása során integrált vállalatirányítási rendszert. Ennek oka arra vezethető vissza, hogy ezek a vállalkozások túlnyomó részben olyan állattartási tevékenységet is folytatnak, ami nélkülözhetetlenné teszi számukra az integrált rendszerek használatát az eredményes gazdálkodáshoz, ugyanakkor nagyobb fokú diverzifikáltság is jellemzi ezeket a gazdálkodó szerzeteteket.

A khi-négyzet próba eredménye alapján egyértelmű, hogy nagyon szoros a kapcsolat és főtevékenység és az integrált információs rendszer használata között. A Pearson féle khi-négyzet alapján p<0,000 ami kisebb, mint a 0,05 érték, tehát erős szignifikáns kapcsolat van a végzett főtevékenység és típusa és a vállalkozás számítógépes információs rendszer használata között. Ugyanezen az 5 százalékos vizsgálati szinten a valószínűségi arány értéke ugyanolyan, mint a khi-négyzet értéke, azaz 0,000. Ebben az esetben ez is a kapcsolat szorosságát, az erős szignifikancia szintet támasztja alá. Ez alapján is szignifikáns a kapcsolat a végzett tevékenységek átlagos száma és a vállalatirányítási rendszer használata között. Ez cáfolja a nullhipotézist, tehát kimutatható a szoros, szignifikáns kapcsolat a két változó között. Azaz a tevékenység jelentős (szignifikáns) módon befolyásolja, hogy használ-e integrált vállalatirányítási rendszert a mezőgazdasági vállalat. 
Az összesített főtevékenység szerinti elemzés birtokában lefolytattam egy részletes, minden egyes főtevékenységre külön kiterjedő vizsgálatot is. Miután rendelkezésemre állt a vállalkozások összesített vizsgálati eredménye, ami szignifikáns kapcsolatot talált, úgy véltem, hogy érdemes részletekbe menő elemzéssel is alátámasztani a hipotézisem. Kereszttábla elemzéssel hasonlítottam össze az egyes főtevékenységeket. A jobb átláthatóság érdekében az SPSS elemzésnél beállítottam, hogy százalékos összehasonlítást is végezzen el a program. Ennek megfelelően az abszolút gyakorisági eloszlás mutatja, hogy az egyes esetek mely kategóriákba tartoznak. A sorszázalék segítségével összegezve is mutatja a százalékos adatokat, ami az értelmezés során tovább segíti munkámat. Ebben az esetben nem tartottam releváns információnak az oszlopszázalék jelzését az ábrán, mivel összegezve szerepel az az adat, ami megfelelő információval szolgál a vizsgált terület kapcsán. Összesített eredményeket mutatják az oszlopok, ennek megfelelően megállapítottam, hogy az elemzés teljes körűen lefuttatható vizsgálat volt: minden válaszadót be tudtam sorolni főtevékenység alapján is.

A 2. ábra részéletezve mutatja, hogy mely területek azok, ahol használnak integrált informatikai rendszereket a vállalkozások: vegyes gazdálkodás, állattartás (szarvasmarha, sertés, baromfi, egyéb állat), növénytermesztési szolgáltatás és gabonafélék termesztése jelenik meg legmarkánsabban, hiszen harminc százalék feletti ezekben az esetekben az informatikai rendszer használata.

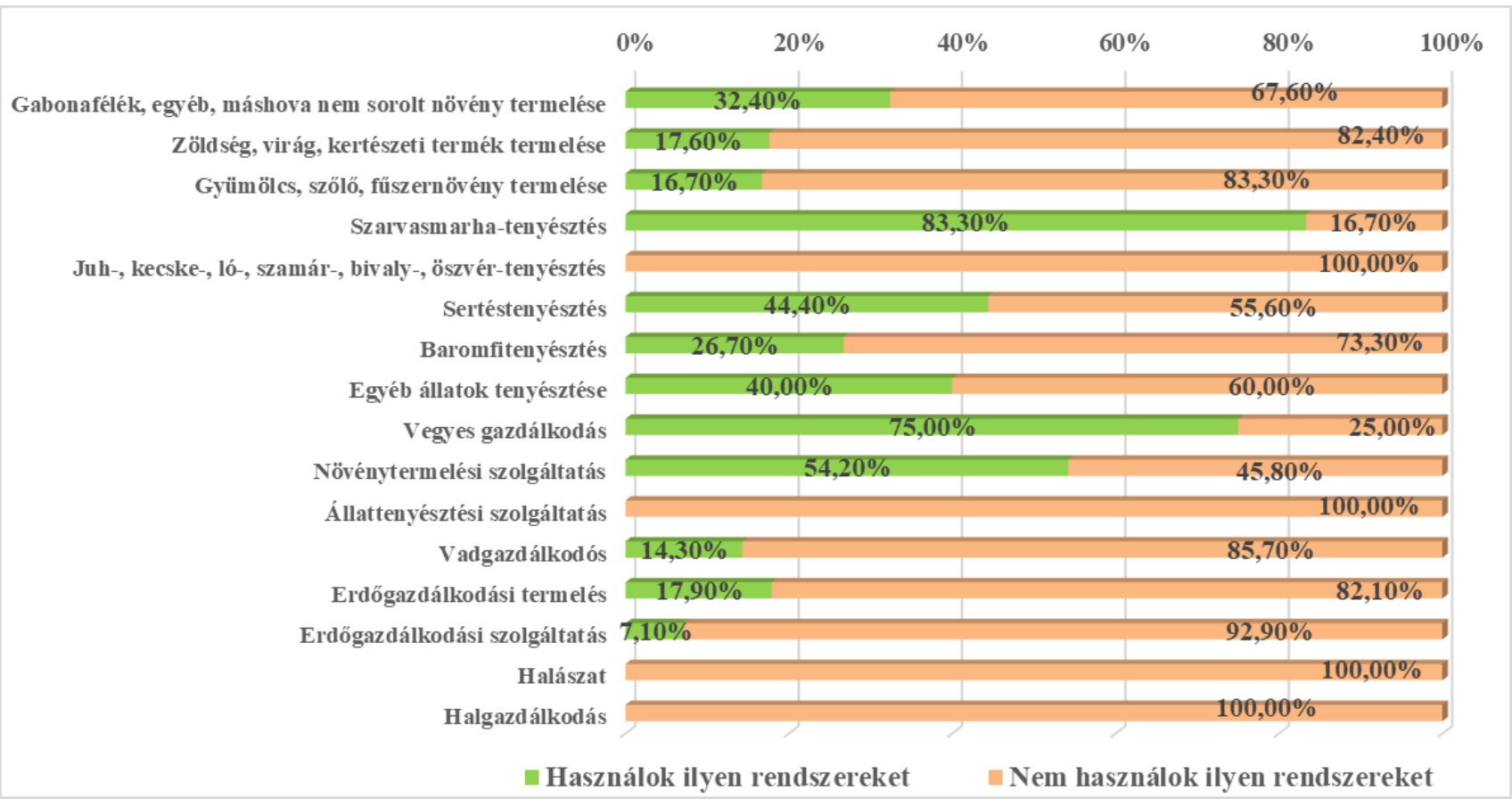

Forrás: Saját kutatás, 2017.

2. ábra Az egyes fötevékenységek és az integrált rendszerhasználat összetétele a kereszttábla elemzés alapján (\%)

Az elemzés eredményeként a Pearson-féle Chi-négyzet próba értékének szignifikancia szintje 0,000, ami kisebb, mint 0,05 szignifikancia szint. Ebben az esetben ez a két változó függetlenségének elutasítását jelenti, vagyis 95\%-os biztonsággal kijelenthetjük, hogy a két változó között szoros, szignifikáns kapcsolat áll fenn, vagyis a főtevékenység jelentősen befolyásolja az integrált vállalatirányítási rendszer használatát. 
Az elemzések eredményeként tehát megállapítottam, hogy a Phi és a Cramaer’s V alapján 0,423 a value érték, ami 0-1 között ad értékelhető eredményt. Ennek megfelelően a kapcsolat iránya alapján pozitív és szignifikáns kapcsolat áll fenn a változók között, ami megerősíti az előző eredményemet. Az eredmény ismeretében elvetettem a nullhipotézist és megfogalmaztam a tézisemet, miszerint Magyarországon a mezőgazdasági kettős könyvvezetésú szervezetek között azok használnak integrált vállalatirányítási számítógépes rendszereket, melyek több tevékenységet végeznek, diverzifikáltabb és összetettebb a tevékenységi körük. Különösen jellemző ez azokra a vállalkozásokra, melyek a tevékenységük során állattartást és növénytermesztést egyaránt végeznek.

\section{Összegzés}

A cikkben bemutatott és kiemelkedően fontos kutatási eredményem, hogy összefüggést találtam a vállalkozás tevékenységének diverzifikáltsága és az integrált vállalatirányítási rendszer használata között. Nagyon szoros kapcsolat áll fenn abban a tekintetben, hogy hány tevékenységet végez a vállalkozás és ez jelentősen befolyásolja az informatikai rendszerhasználatát is. A mezőgazdasági vállalkozások esetében mindig nagy dilemma, hogy kevés és speciális tevékenység vagy sok lábon állás jellemezze őket. Ennek eldöntése nem egyszerű feladat. A javaslatom a tevékenység diverzifikálása, amit két részre osztok szét. Az egyik, hogy a jelenleg is diverzifikáltabb vállalkozások hatékonysága fejleszthető az IKT és vállalatirányítási rendszerek használatával. A vezető és a tulajdonos jobban és gyorsabban képes átlátni a munkafolyamatokat, könnyebben elemezhetőek a pénzügyi mutatók és szűrhetők ki az esetleges problémák. A másik vetület: a jelenleg kevésbé vagy nem diverzifikált mezőgazdasági vállalkozások tevékenység bővítésére lehetőséget ad a vállalatirányítási rendszerek használata. A vezető több termelési folyamatot képes egyszerre átlátni és felügyelni, melyekben jól mérhető azok eredménye, és szükség esetén lehetőség van a gyors beavatkozásra. A tevékenység bővítésből az adott térség is profitálhat, mert új munkahelyek jöhetnek létre és ez lehetőséget biztosíthat a munkaerő részbeni helyben tartására, esetleg visszacsábítására.

\section{Hivatkozások}

[1] Ansoff, H.I. (1957): Strategies for Diversification; Harvard Business Review, 35(5): 113-124.

[2] Babbie, Earl (2008): A társadalomtudományi kutatás gyakorlata; Balassi Kiadó; Budapest

[3] Bakos F. (2001): Idegen szavak és kifejezések kéziszótára; Akadémiai Kiadó; Budapest; . p.346.

[4] Berta, 0. (2018): Információs technológiák használata a magyar mezőgazdasági vállalkozások menedzsmentjében: avagy egy digitális agrárgazdasági kutatás eredményei GAZDÁLKODÁS 62 :4 pp. 337-352. , 16 p.

[5] Brace, Ian (2008): Questionnaire Design: How to Plan Structure and Write Survey Material for effect Market Research; Kogan Page, London\& Philadelphia; 2nd Edition

[6] Hamza E. (2011): A diverzifikáció főbb összefüggései a mezőgazdasági vállalkozásokban; Gödöllő, $\mathrm{PhD}$ dolgozat; https://szie.hu//file/tti/archivum/Hamza Eszter ertekezes.pdf; Letöltve: 2017.09.30.

[7] Hunyadi L. - Vita L. (2008): Statisztika I-II.; Aula Kiadó Kft., Budapesti Corvinus Egyetem 
[8] Kinsella, J. S. Wilson, F. de Jong and H. Renting, 2000. Pluriactivity as a livelihood strategy in Irish farm households and its role in rural development. Sociologia Ruralis, 0/4:481-496.

[9] Kovács G. (szerk.) (2009): Kockázatok és kockázatkezelés a mezőgazdaságban. Agrárgazdasági Tanulmányok. 6. szám AKI, Budapest. p. 22.

[10] Lázár E. (2009): Kutatásmódszertan a gyakorlatban az SPSS program használatával; Scientia Kiadó Kolozsvár

[11] Szabóné Berta 0. (2019):

[12] Szakál F. (2000.): A mezőgazdasági vállalatok alapvető gazdasági döntési problémái In: Buzás Gy. - Nemessályi Zs. - Székely Cs. (2000): Mezőgazdasági üzemtan I. Mezőgazdasági Szaktudás Kiadó, Busapest. pp. 174-175.

[13] Székelyné Raál É.: Kettôs könyvvitelt vezető mezőgazdasági, vad-, erdőgazdálkodási és halászati szervezetek név- és címjegyzéke; Budapest, AKI 2010. https://www.aki.gov.hu/publikaciok/ Letöltés: 2011.05.26.

[14] Z. Karvalics L. (2007): Az információs társadalom; Gondolat - Új Mandátum Budapest; ISBN 978 9636930615

\section{Internetes hivatkozások}

[1] Internet 1: http://www.bauernverband.de Letöltés: 2018.01.05.

[2] Internet 2: http://elelmiszer.hu/cikk/magyarorszagon docog az agrarium digitalis atalakitasa; 2017.02.22. Prega Konferencia összefoglaló; Letöltés 2017.12.20.

[3] Internet 3: Eurostat: Farm Structure Survey adatbázis http://epp.eurostat.ec.europa.eu Letöltés: 2015.05.20. 